\title{
Assessing Nigeria's National Communication Policy's Capacity to Address the Challenges of Its Film Industry
}

\author{
Ubong-Abasi Usoroh \\ School of Media and Communication, Pan-Atlantic University, Lagos, Nigeria
}

\begin{abstract}
This paper assesses a portion of Nigeria's national communication policy being policies on the film industry. Its perspective is that although the media policy appears comprehensive as it attempts to address its fundamental ideology and purpose being national development, promotion of national culture and the advancement of individual standards of living through film and its proceeds, the policy on film is monotonous, theoretical, and lacking in key challenging areas faced by the industry. Hence, the paper's position that the policy is outdated, slow and grinding to a halt in applicability as it is addressing broad national film objectives and not focusing on the pressing issues and minute details that add up to ensuring that the broader objectives are achieved. In other words, the national policy as regards the film industry needs to be updated to address current film industry challenges, take cognizance of minute setbacks while enacting policies that will help avoid certain anti-national media policy ideology and guide in the implementation of the updated policy.
\end{abstract}

Keywords: Nigeria Film policy, Nigeria's National Communication Policy, Nollywood, Nigeria's Film Industry DOI: $10.7176 / \mathrm{JAAS} / 72-03$

Publication date:May $31^{\text {st }} 2021$

\section{Introduction and Background}

The relevance of media and communication cannot be far removed from Nigeria's development and its colonial past. It is said that the media is the pipeline through which communication flows (Baran, 2009). For this to happen within the context and purview of a certain jurisdiction, there must be guiding principles regulating the use and administration of these media and communication systems. These guiding principles are often tagged media policies.

Nigeria has one of the most organized yet controversial media policies in Africa even as it fights to maintain its position as the giant of Africa. Scholars from within the academia have assessed different facets of Nigeria's National Communication Policy and have arrived at bipolar or complex conclusions amidst insightful recommendations geared towards National growth and development, media infrastructural growth and capacity building as well as the improvement of standards of living of practitioners and Nigerians. While some have been positive and optimistic, others have been negative and pessimistic as some scholars have reached a consensus on the views that the Nigerian National communication and media policy is incapable of addressing Nigeria's media and communication systems, it's challenges as well as its developmental goals. A few such as Uwom and Alao (2013) as well as Esiri and Okunade (2014) have submitted that the policy statements are broad, ambiguous, and not suited for administering Nigeria's media and communication structures and its development.

Along the line of these observations and submissions, this paper sets out to investigate the media policy focused on film in line with realities in Nigeria's film industry, and to ascertain the potency of these policies in addressing issues in Nigeria's film industry. The aim is to arrive at a position on whether the national media policy on film is enough to address the challenges and developmental strides of its film industry. The article addresses an aspect of the Nigeria National Media and Communication's Policy on film drafted within an unsettled democracy.

Unified views hold that the Nigeria National Media and Communication's policy of Nigeria came into existence through the conclusions and recommendations arrived at a seminar organized at ASCON, Badagry in 1987 by media scholars, practitioners, and some other major stakeholders (Uwom and Alao, 2013). According to Esiri \& Okunade (2014), the policies emerged because of a rigorous one-week seminar planned and coordinated by the Federal Ministry of Information and Culture in partnership with a committed group of specialists in mass communication's central and related fields of discipline. The National Communication Policy was founded and grounded on the platform of the 1979 constitution of the federal republic of Nigeria and have been reviewed three consecutive times in 1999; 2004 and 2010 (Uwom and Alao, 2013). Within these time frames, meetings have been held to review and document the policies reviewed, but Uwom and Alao (2013) posit that no single document officially called Nigeria's National Mass Communication Policy exist in Nigeria. Most academic articles posit that various papers exist for different spheres of media in Nigeria; highlighting the major policy dictates as regards specific sub-sectors in Media such as Electronic, Print, Film, Advertising and Public Relations (Esiri, \& Okunade, 2014)

On the background of Nigeria's film industry and its connection to media policy, Adesokan (2012) submits that contrary to the Kenneth Nnebue narrative, the Nigerian film industry began way back around 1960 - not inclusive of the Glover Memorial Hall 1903 experience where the first foreign celluloid film was screened in 
Lagos. The consensus according to Idachaba (2018) is that the era where a generation of touring Yoruba theatre experts and Nigerian spurn celluloid film formats were produced by movie makers such as Hubert Ogunde, Ola Balogun, Jab Adu, Moses Olaiya (Baba Sala), Adeyemi Afolayan and Eddie Ugboma - marked the origin of Nigeria's film industry. This era was succeeded and sustained by a series of 1970 movies, the filming of Kongi Harvest, a play written by Wole Soyinka and produced by Francis Olalede and an infinitesimal government interest and presence in the movie trend (Idachaba, 2018). This era gradually made way for the emergence of the video film era where Kenneth Nnebue's 1992 Living in Bondage video format title became the most popular home video film supplied in VHS tapes; and it heralded an English-speaking side of Nigeria's film industry generally known as Nollywood (Onuzulike, 2008).

It does appear that while the Nigerian Film Industry was experiencing humongous early advancement, the media policies for film had not been in place until after 1987 when the ASCON meeting was held to draft out and institutionalize the policies. Hence, the belief that the film industry grew unregulated by the government and remains informal in nature as it is currently sustained by market forces (Lobato, 2012). The fundamental regulatory framework had been the nation's constitution which was great but needed a more defined and industry focused policy to direct the affairs of Nigeria's film industry.

\section{Statement of Purpose}

This paper intends to assess a portion of Nigeria's national communication policy being policies on the film industry. Its perspective is that although the media policy appears comprehensive as it attempts to address its fundamental ideology and purpose being national development, promotion of national culture and the advancement of individual standards of living through film and its proceeds, the policy on film is repetitive, theoretical and lacking in key areas of challenges the industry is facing. Hence, the paper's position that the policy is outdated, slow and grinding to a halt in applicability as it is addressing broad national film objectives and not focusing on the nitty gritty/ minute details that add up to ensuring that the broader objectives are achieved. In other words, the national policy as regards the film industry needs to be updated to address current film industry challenges, take cognizance of minute challenges and policies that would help avoid certain anti-national media policy ideology and guide in the implementation of the updated policy.

Whereas this current media policy on film may have sufficed for the early post colonization era, this current dispensation as well as the realities of the film industry increasingly exposes the lacunas and weaknesses of the media policy focused on film. It shows that the policy currently lacks the pre-requisite to guide the development of a dynamic and changing industry such as Nigeria's Film industry. The exhibits for this argument highlight the practical and realistic trajectory of the film industry against the policies outlined on paper. It recommends a revisit of the policies outlined for the film industry to enable a streamlined and regulated growth of the industry in line with national interests/ benefits and the advancement Nigeria's media systems.

To achieve the purpose of this paper, the outline of the policy pertaining to the film industry will be briefly outlined. Thereafter, there will be a brief definition and clarity on what a policy statement should be and do. This will be followed by an outline of the key policies aimed at the film industry and the theoretical basis for this argument. Afterwards, key issues plaguing the policy will be highlighted and discussed; then closely followed by an outline of realistic and observable issues plaguing the film industry which will be used to assess the policy dictates to see how robust the policies are in either theoretically guiding or addressing the current challenges faced by the film industry.

These issues will be treated along the lines of

1) Piracy and Intellectual Property Infringement

2) The ethnic division within Nigeria's film industry (Igbowood, Yorubawood, Kannywood, Akwawood)

3) Long standing lack of governmental support

4) Mute position on controversial issues in content

i) Objectification of females in home videos

ii) Negative Image Branding of Nigeria as diabolic and rough

iii) Female gender role stereotyping in home videos

iv) Ethnic Stereotyping

v) Domestic Violence

The aim is to argue that the National media policy for film is not comprehensive, updated and robust enough to guide the management of an ever dynamic and complex film industry like Nigeria's film industry. Furthermore, the policy statement in some cases do not apply to the current state of affairs or realities of Nigeria's film industry and is in some ways not in line with the fundamental ideology for which the policy was established (National unity and development, citizenship's advancement and growth of democracy).

\section{A Brief Run Down of The National Policies Focused on Film}

Excerpts from the reviewed policy document of 2004 and 2010 for the film sector within Nigeria's media system 
stipulates the following guidelines for film:

(a) To establish a virile profit-oriented film industry;

(b) To serve as a vital instrument for national integration, unity and international image building;

(c) To protect our rich cultural heritage;

(d) To serve as a tool for national cohesion;

(e) To expand Nigeria's sphere of influence through export of our cultural values;

(f) To serve as a vehicle for public enlightenment, education and entertainment;

(g) To encourage the production and exportation of Nigerian films in view of the potential of film as earner of foreign exchange.

Other objectives of the film industry according to the 2004 review document are as follows:

i. To promote Nigerian culture as the basis of creative expression and relevance in media, arts and sciences;

ii. To reinforce the positive aspects of our cultural heritage and discourage all negative values;

iii. To serve as means of developing arts, culture film/video as platforms and instruments of national integration, international image-building, the enhancement of Nigeria's leadership role in Africa and its commitment to the advancement of democracy;

iv. To serve as a source of education, leisure, entertainment and a means of advancing the peculiarities of our nationhood while contributing to human thoughts and civilisation as well as cultural transformation;

v. To encourage the establishment of a virile, self-sustaining, profit-oriented film/video industry driven by the private sector;

vi. To encourage the production and exportation of local films and video;

vii. To protect, project, and propagate Nigeria's rich cultural heritage and values through cultural exhibitions and film/video.

viii. To educate, enlighten, mobilise and sensitise the people through film/video, by propagating national values which promote patriotism, national pride, solidarity, aspirations and consciousness;

ix. To facilitate the advancement of national unity, social co-existence, education, science and technology and the peaceful resolution of social problems and conflicts.

(Uwom and Alao, 2013, p67-68; Nigeria Community Radio Coalition, 2012, Online)

\section{What Should A Policy Document be or do?}

For Van Cuilenberg and McQuail (2003), all media policies possess an identifiable set of elements which clearly delineates their morphology as a media policy. These elements can succinctly be put as goals and objectives, values or criteria through which targets are defined and identified, content and communication offer where policy applies, the various distribution services as well as measures to policy implementation. In a practical scenario, Opubor, Akingbulu and Ojebode (2010) posits that although political systems direct the types and forms of media policies as well as the values, the aims of a media policy can be observed and analyzed in terms of the practical and tangible realities/issues they address within a nation.

\section{Theoretical Framework - Development Media Theory and Democratic Participant Media Theory}

The national media policy's core grounding and ideology, goals and objectives focus specifically on the promotion of national development and interests, advancement of the citizenry and the liberalization of media systems. These fundamental positions bring to mind two important normative theories of the media that will be deployed to guide the context and boundaries of this discuss. Propounded in 1987 by Dennis McQuail, the development media systems of press theory states that media within developing nations must play a primary role geared towards facilitating and fostering development. In line with this, media should be used for the overall good of the nation i.e. the media must succumb to be used by the government as instruments and agents of development, economic, political, cultural and national growth (Asemah, 2011; McQuail, 2005). Within this political context development Media Theory supports the premise that media must not directly challenge the government. Rather, national growth and development must be the media's primary objective and prioritized over press and individual freedom - hence the core guideline detailed as follows

- Media must take on constructive development responsibilities consistent with recognized national policies.

- $\quad$ Press Freedom should be regulated to align with the economic priorities and development needs of the society.

- Media must give priority in news and information in an interconnected line with other developing countries geographically, culturally and politically close.

- Media workers are forced to function as information gathering and dissemination capacity as far as their goals align with that of national development.

- The state exclusively regulates the media for proper management and to ensure national developmental goals are achieved (Asemah, 2011, pp.151-154; LittleJohn \& Foss, 2009). 
As a supplementary framework, Democratic Participant Media Theory propounded by Dennis McQuail in 1987 appealed as another core normative theory that applies to the context and aims of the national media policy. It states that individuals deserve access and ownership of media systems. Thus, they should be given privileges to own media establishments and participate to ensure pluralistic views in society (Asemah, 2011, p.154). This theory supports pluralism and decentralization in place of monopoly and centrality (Yaroson and Asemah, 2008). The purpose then is to ensure that every citizen can have a platform to express views and, in some ways, contribute to governance.

As a theoretical base and principle on which the nation's media policies were built, these two theories project a robust fundamental objective which is nation and capacity building although some would have an opinion on the development media theory's undermining elements such as the way it presents African nations and as restrictive of press freedom as it places the media as tools and puppets in the hands of the government and politicians in some ways appealing like a subtle authoritarian style of media management and regulation. In line with the core theory and policy objective, one would expect that the policy makers remain abreast with the challenges across national media sectors to constantly update policies to fit and carter for the current and strong challenges in line with policy principles and foundations.

\section{An Assessment of the Media Policy on Film, Policy Ideology and the Realities of the Film Industry}

Most statements on the media policies on film can arguably be categorized as they are repetitive and reiterated across other film policy statements within the document. Several instances abound to prove this position. For instance, the first statement (i) which is to operate a virile and profit oriented film industry was repeated and implied across policy statement $(\mathrm{g})$ and $(\mathrm{v})$. The same position applies for (b) To serve as a vital instrument for national integration, unity and international image building; which was as well repeated and implied in (d), (vi), (vii), (viii), (ix). For (c), the same purpose was repeated in (i). Film policy statement (f) was reiterated in (iii) as well as (ix). This was further emboldened where statement (g) sounded similar to (vi) and (e) statement was implied in (ix) as well. This presents the media policy on film as robust and comprehensive when its repetitive nature which would have been deployed positively to address policy statement in details became a restatement of what had been earlier stated.

From a grid perspective, one can summarize and group these policy statements on film into five major groups being profit driven goals, solid position on national unity and positive image portrayal of Nigeria for national and international audiences, protection of the nation's cultural heritage, promotion of awareness on national identity and its core values, films use for purposes around enlightenment, education and entertainment, encouragement of film production and export for profit purposes. This attempt to group the policy statements is as well wrecked by repetitive positions restating the obvious as it has in some cases been already stated.

What is however encouraging is the fact that the policy's focus on film has been consistent with the core objective and ideologies of national development. The purpose for this brief analysis is to highlight the fact that these policy statements seem somewhat broad as an objective, repetitive and not in line with some of the contemporary challenges bugging the industry, hence the submission that the policy is not advancing with the film industry and its morphology. In a bid to drive home this argument, some of the issues below will further buttress this paper's position as it relates to the Nigeria National Media and Communication's Policy specifically on film.

\section{Piracy and Intellectual Property Infringement:}

It is no longer questionable the stance that Nigeria remains within the top three ranks of the most prolific nations in terms of film production. With this blessing came its bane - piracy which has eaten deep into the very fabrics of creativity discouraging a lot of creatives from further exploring their passion. Tade (2016) and Oyekanmi (2017) have submitted that statistics have shown that Nigeria loses between \$1 - \$2 Billion annually to piracy even as the depth of piracy in Nigeria has further been deepened by internet access and the free streaming and downloading platforms. Furthermore, Oyekanmi (2017) had grounds to proof that Nigeria's film industry's informal structure has been one of the core reasons why investors, co-production collaborations as well as formal international distribution opportunities have often eluded film makers in Nigeria.

Observable instances abound where pirated copies of movies flood the streets of Lagos and other regions of Nigeria a week or two before a well anticipated movie's premiere in the cinema. For instance, Tade (2016) reports that of July 2014 where high definition copies of Chimamanda's Half of a Yellow Sun was found in film stores and with hawkers within core Nigerian metropolis, weeks before its premiere. The story is similar for the film title October 1 and the multi-million-dollar movie investment - The Wedding Party $1 \& 2$, found on the streets of different states in Nigeria for 500 naira per copy and available as well as free online on streaming and download platforms. (Ochuwa, 2017). It is on record that this debilitating challenge has on many occasions forced an outburst on the part of film makers. For instance Afolayan - a renowned prolific film maker and contributor to Nigeria's income in the film sector threatened to take his trade overseas due to the loses he has sustained as an individual and as a corporate film entity being heavily taxed for film and also loosing on both ends to pirates (Tade, 2016). 
These instances highlight the dilapidating nature of the industry and sheds light on policy's lacunas and incapacities. It also highlights the policy's inability to not only keep up with the pace of the industry but also the policies inability to commit to its own commitment of building a "virile profit-oriented..." film industry. Where the policy makes no mention of this challenges or the way forward to exiting this current challenge, there will be little to nothing done towards implementation of a policy that does not exist.

The position of no mention of ways to evade the scourge of piracy was also observed by Adesanya (2005) who observed in his article that all the relevant laws and policies that impact on the industry from the film policy, were silent on the issue of Piracy and Rights Acquisition of Nigerian films and videos."

Chowdhury et al (2008, p32) who also observed a missing link between anti-piracy objectives and Nigeria's film industry policy recommended an anti-piracy policy whose implementation must be proactively spear headed by industry experts who understand the terrain and the challenges of the sector.

Granted, copyright laws and some other statutory laws have clearly stated their positions against the various hydra-headed forms of piracy and intellectual property infringement. However, it is expected of the policy dictates especially that focusing on the film industry (even in its 2010 updated form) to state and tackle issues in line with the challenges of the industry in a bid to conform to its commitment and mandate to keep up with the regulation of the film industry. The sad reality however is that the policy lacks any tangible mention or approaches to consciously avoiding the scourge of piracy being one of the most feared enemies of progress within the creative industry. This position is of concern as it remains evident that even in policies addressing electronic media, no mention is made around tackling issues of piracy yet there are forward thinking statements such as that which supports the development of a profit driven and prolific film industry. One does not need to brainstorm too far to observe that this statement counters the reality of Nigeria's film industry as no form of productivity or sustainable profit-oriented film entity can thrive in a space where piracy and intellectual property theft is drowning every perceivable output and discouraging creative forms.

Encouraging the institution of a self-sustaining and profit oriented film industry within policy documents does sound far removed from the ideal goal of establishing policies to drive a conscious effort towards establishing a full-proof funnel system designed to avoid piracy pre and post content creation processes and eliminating its scourge across the supply chain by prescribing somewhat serious and terminal punitive measures in place to totally discourage piracy and intellectual property theft. This could be followed by a formalized document in place to structure the deployment of law enforcement assets at intervals to ensure compliance as well as the protection and sustenance of the film culture and its proceeds as a treasured and core productive sector to the national GDP. The issues plaguing the film industry's advancement and as well missing in policy dictates transcends piracy and intellectual property theft to ethnic division within the sector and amongst film makers, casts and crews.

\section{The Ethnic Division Within Nigeria's Film Industry (Igbowood, Yorubawood, Kannywood, Akwawood)}

The position on ethnic biases and misunderstanding as a rudimentary cause for disunity remains a unanimously agreed upon theme across national and academic discourses in Nigeria. Building from Haynes (1995) observation where he submitted that he observed a marked division/antagonism between the Yoruba film maker and others at the National Film Corporation held in May of 1992 to work on film policy, it is then surprising to see that the very media policy built to also direct the affairs of the film industry is lacking in an area that should propose unity amongst film makers across the nation seeing that the policy statement on electronic/film and print media takes a strong position on broadcasting media pieces that must promote cross-ethnic unity and national peace.

The ethnic tensions pervade all ramifications and sectors of Nigeria's industry. What this implies is that the film industry has had its fair share of ethnic biases and breakaways in processes of film production, distribution and film consumption. This is exemplified in the chaotic factions within the Nigerian film industry who do not just fight for the establishment and administration of an ethnic focused film industry but also among themselves for the leadership positions within these factions (Okikiapp, 2017; Anyanwu, 2015). Some scholars such as Maton (2018) have observed that there seems to be an invisible wall restricting the amalgamation of movie makers across ethnic spaces and in one body, speaking one unanimous voice except on a film production project basis which is only facilitated and sustained by personal interests and expectations. These factions being Igbowood, Yorubawood, Kannywood and Akwawood according to Maton (2018) is no different from the existing socio-political situations in Nigeria and is robbing Nigeria's entertainment sector of the benefits and rewards of multi-cultural collaborations which utilizes and meshes knowledge, experiences, values and cultures from different angles of life into the building of a sustainable industry and art pieces produced; which then appeals economically as well as socially to a wider national and international audience and cultural spectrum as it speaks value.

An instance of the possibilities in collaborative productions can be exemplified in The Wedding Party that grossed over 3.5 billion Naira, making it the highest grossing film in Nigeria to date despite the piracy scourge it suffered (Vourlias, 2017).

According to Okiche (2017), the unrivaled success was as a result of "strategic collaboration between filmmakers, unbridled ambition, a finely assembled cast, a story that resonates, excellent marketing and publicity 
skills, a calculated release date, welcoming reviews, strong word of mouth and an audience that is open to be entertained" (Okiche, 2017, par. 45).

The issue of unity from amongst film makers remains vital to the maximization of Nigeria's film industry's potential. If this observation is true, then the subject of unity need not be just a policy guideline or message for broadcasters who broadcast information using different formats and media to the populace to achieve national unity and peaceful ethnic coexistence, it should also be positioned in the film policy document and aimed at Nigeria's film makers, promoting benefits/ rewards of collaborative work to foster and drive the national media policy goals.

Following this line of thought, one would expect that this sort of objective (which applies to Nigeria's film industry current reality) would be clearly reflected in the film policy guiding the affairs of this sector as it does seem to raise concerns and does counter the status and some dictates of the policy's pro-peaceful ethnic coexistence and national peace and unity stands. The opposite however is the case as this line of policy thought seems to be missing from those guiding the business of Nigeria's film sector. The dictates of the document rather focuses on general normative areas of nation building, cultural preservation as well as perceivably ambiguous statements such as those observed in dictates ii, iv and viii of the national media policy focused on film.

To hone in on this discuss, the proposed position is not to have a policy statement that drives towards one Nigerian film industry in structure deploying a central language (English) as the means of communication and named "...ollywood" as is the case with Nollywood which some scholars like Schnell (2017); Lobato (2012) and McCain (2013) find as a total reduction of a rich and diverse industry to one English speaking entity secondary to Hollywood. Rather, the perspective is to have a policy that ensures that this multi ethnic industry is one in nature, element, regulatory structure, bond and voice but flexible in nature to deliver on either language or ethnic specific content (which must as well present a unanimous cultural front for Nigeria), administration and production plans as against its current nature which is informal, chaotic, conflict ridden and controversial.

\section{Long Standing Lack of Governmental Support}

According to Ibagere (2015), one of the major challenges plaguing and hindering the growth of Nigeria's film industry is funding and governmental support. These remain evident in areas of tax reliefs and breaks, eradication of piracy and provision of facilities and equipment for film production. While Onyekanmi (2017) and Chowdhury (2008) had perceived the absence of government's assistance on the film policy document and recommended that policies be made favoring the growth of the film sector with the assistance of government backed support structures, it is pertinent that one takes a second look at the policy, then zooms out a bit to assess this issue from a global perspective. From a global perspective, Unctad (2008) had explained that the government and the policies in place are usually the backbone of strong creative industries like that of the UK and the US. Unctad (2008) narrates that in the UK, the government had undertaken the task of supporting and promoting the growth of the film industry as outlined in the cultural and creative industry policy that clearly delineates how and when filmmakers experience tax reliefs and breaks, processes aimed at fund raising for the industry, what new facilities must be built or maintained, the number of individuals to be trained per time amidst other developmental strides which also develops their creative cities, clusters and the film industry offers as a whole as skilled professionals can freelance, be offered contract or permanent jobs or earn and create wealth from exploiting their intellectual properties.

Given, the policy statement details a position on "building a self-sustaining virile profit-oriented film industry". But then, for an industry to be self-sufficient, it must have undergone a foundational grooming, formalization and support phase often led by the government. This is the crux of the problem as the Nigerian film sector has experienced very little government support, not enough to rightly place the film industry on a selfsustaining pedestal. Hence, the believe that policy statement in vague and unable to guide its own commitment and some real-life issues faced by the film industry.

On this, the paper's perspective then is that the film policy has failed at its fundamental task of grooming the film industry to a self-sustaining position. This is because the Nigerian film industry is known to have thrived on its own without much of government's support. According to Miller (2012), the film industry is fairly unregulated, informal and seemingly off government support radar but driven by private business interests and venture capitalists often tagged 'marketers' who exploit the reigning fetish and diabolic storylines and distribute same with the hopes of cashing out while the storyline resonates with its audience. The same position is maintained by Lobato who posits that the industry is not government funded and driven as it is largely informal, loosely regulated, utilizing informal and risky distributive networks (Lobato, 2012).

The Nigerian film sector has grown to a point where it's English speaking area is speculated to be the second most prolific film industry in the world dominating screens across the world and producing over 50 movies every week (Larkin, 2004; Offiah, 2017). Nigeria's English-speaking film industry often called Nollywood does not just dominate domestic screens across Europe, it is as well known to be a dominant influence and entertainment force within sub-Saharan Africa (Miller, 2012). Nationally speaking, "Nollywood" employs over a million Nigerians (Obafemi, 2015) and contributes an estimated annual revenue of over \$800 million to Nigeria’s GDP (Tijani, 2018; 
Offiah, 2017).

The industry reached this pedigree without much of direct support from the government aside the liberal film environment offered movie producers and a few difficult to access grants such as the Nollyfund. What is shocking as regards the media policy and the lack of support from the government is the observation that for a policy whose aim is to achieve national growth and development in all ramifications as well as the improvement of standards of living of its citizenry through numerous ways, inclusive of the promotion of Nigeria's cultural heritage and culture; one would have expected that the government would play a major role in initially pushing film policies aimed at formalizing, grooming, supporting and funding its film industry to a self-sustaining position based on its commitment to national growth/citizenry development and from the observation that the film industry had gradually metamorphosed into one of the most productive and yielding sectors towards the nation's GDP - hence the need to encourage its continued growth.

The absence of guidelines in place to foster, direct or administer some form of support or formalization aimed at the encouragement of growth and development for the film industry and in line with their policy aims and commitment speaks a lot about the policy's inability to drive growth as it does seem not to be committed to its ideologies while addressing core need areas of the film industry. Areas highlighted by BizzbeeSolutions (2016); Buitrago \& Duque (2013) and Chowdhury (2008) to be:

1. The need to establish a system that offers tax reliefs, breaks and holidays either for contents presenting a positive portrayal of Nigeria, its cultures, heritage and values.

2. Policies to discourage piracy and encourage the enforcement of copyright laws and intellectual property rights laws and policies to protect content and hardware.

3. Enactment of training hubs for training and reorientation of film experts and intending film makers who are interested in exploring the art of film making or music production in line with media policy's core objective which is the promotion of national unity and peace as well as the advancement and adoration of Nigeria's cultures, core values, identity, norms, heritage and tradition.

4. Proper funding needed to support and sustain deserving film makers as well as amateurs as they launch out to service provision either in the lines of entrepreneurship, consultancy, collaboration, job creation or freelancing in different areas across Nigeria's movie industry

5. Policies in place to ensure state of the art equipment and proper production facilities are in place to spike improvement in the production quality and standard of local/home-made content.

6. Formalization of official and suitable film delivery channels to ease content distribution, accountability, tracking as well as monitoring of content usages.

7. Delegation of tasks matched with institutionalization of administrative, regulatory and enforcement bodies needed to administer/manage activities and operations of Nigeria's film industry in a bid to save the sector from collapse (Offiah, 2017; BizzbeeSolutions, 2016; Buitrago \& Duque, 2013; Chowdhury, 2008).

Owing to this observation, the national media policy in line with its aims of national development and growth of the citizenry would ideally require a revisit if it must appeal as a more sensitive and applicable document tailored to fit and drive fundamental policy ideologies and developmental problems currently faced by experts and personnel in the film industry. This would be done to commit totally to the key ramifications of the policy's main objectives and to demonstrate its bespoke nature in relation to the current trend of issues confronting Nigeria's film industry.

\section{Mute Position on Controversial Issues in Content}

A majority of Nigeria's film industry contents have been known within scholarly circles to be plagued with controversial and negative issues partly because the Video's Censors board may have been overwhelmed in its censorship tasks hence the oversights or maybe as most scholars would highlight as a fundamental problem - the height of exposure and enlightenment of most Nigerian film makers on national positions as regards trending core and sensitive issues as being poor. These issues transcend ethnic and gender stereotyping; unguided presentation of domestic violence; negative image representation of Nigeria as a diabolic, rough and unsafe country; Objectification of females in the film industry and an array of other budding issues. These has been areas of concerns within the academia. For instance, Ibbi (2018) and Nwafor (2013) frowned at Nollywood's stereotypical portrayal of the female gender as inferior, and irrational beings fit only for domestic and sexual roles and only assertive when they are in competition with a fellow female. Ibbi (2018) in his recommendation called for a proper understudy of society by screenplay writers before screen plays are scripted. This is in line with aims of not misleading the public. Shaka and Uchendu (2012) on the other hand are concerned with the spillover of a patriarchal society into screen media resulting in the representation of women as manipulative and seductresses, vile and dangerous, extremely emotional and not to be taken seriously, beings made only for home and domestic activities. Similarly, Olushola (2016) in his article observed that women are depicted in Nollywood as unambitious domestic servants, warm and incompetent and disapproved this representation noting that Nollywood is 
normalizing and reinforcing this belief as it continuously projects these subtle messages in film. From a certain angle, one can pin this anomaly to a weakness in national media policies aimed at the film industry and its inability to keep pace with the dynamics and ever-changing nature of the industry and to take a stance on issues such as this.

Away from stereotypical portrayal of women, other issues abound such as the negative image representation of Nigeria as a diabolic place. Alawode, (2013) in his article was not pleased with the height of negative portrayals of ritualism in Nigerian movies. He projected that more than forty-six instances of negative ritual portrayals were observed in his content analysis of thirty random Nigerian films. While he held a position on the fact that Nollywood is demonizing of African traditions through wrong and negative portrayals, his recommendation was that a balanced portrayal of its good side must be promoted as ritualism is a two-sided activity. Ezegwu et al (2016) in their article frowned at the underlying drive blindly leading film makers to produce themes in line with witchcrafts and voodoo noting that the sad reality is that it resonates with the audience and records high returns on investment hence the continued production and patronage. Their position is that, diabolic representations are not aiding Nigeria's developmental objectives and positive brand image portrayal. Hence, the need to revert to themes in line with cultural values and promotion of rich cultural heritages.

These trends directly work against one of the core media policies which is aimed at promoting a positive brand image of Nigeria to encourage foreign investment and tourism. The absence of policy statements detailed enough to address these issues, spotlight the ineffectiveness of the media policy aimed at the film industry to address and keep up with emerging issues of concern within the film industry.

The trending issues also being ignored by policy makers include female objectification in Nigerian home videos and sometimes cinema titles. Ver (2012) in delineating how females are objectified in Nollywood films, framed indecently in erotic and provocative clothing, valued for their body or certain parts of their body and sex appeal implied that it does appear that the industry really has no direction, vision and a fundamental ideology. From a certain perspective, one can as well link this position to the lack of a policy guiding and clearly delineating its position on this sort of portrayals and representations. The view on Nollywood's objectification and misleading portrayal of females remains an agreed upon position across the academia even as Onyenankeya, Onyenankeya, and Osunkunle, (2019) as well as Kaks (N.D) have offered their position on the issue as being a degrading trend in Nigerian films. A synopsis on their position is that this trend projects an insensitivity on the part of film makers as it continuously impacts negatively on the image perception of the females in Nigeria. Again, from a certain angle, this degrading female objectification trend highlights a weakness in the film policy's inability to address this sort of issue, highlighting the nation's core ideology on issues of female objectification in film. It also presents a certain vibe projecting the policy maker's inability to keep up with the pace of the film industry.

Ethnic stereotyping is another area of concern making the waves in Nigeria home videos. The subtle and sometimes obvious comments along boxed and blanket ways of viewing individuals from certain ethnic entities presents another area of concern where policy on film seems to pay little attention. Given stereotyping also works both ways - positive and negative. The position in film appears mostly focused on negative stereotyping. For Instance, in films, Edo girls are often presented as females who are harlots and ply their trade in Italy, Calabar males and females are often represented as illiterates, servants, subservient fellows with high libido levels, Igbo men are money lovers, Hausa men are often seen as direct, unforgiving and extremely religious men whereas their money exchangers are often represented as dubious. Some intellectuals have observed this issue as well and offered a perspective. For instance, Adegbembo (2017) also observed that as with real life, Nigerian media is promoting stereotypes. Along these lines, Yoruba's are seen and projected as loud, polygamous people who breed babies they cannot groom; Northerners often Hausa speaking fellows perceived as dagger wielding subservient group of people, Benin residents are perceived as experts in witchcraft while Igbos are viewed along the lines of mindless money lovers who will sacrifice anything and anyone to get money. While Adegbembo's (2017) position projected that individualism applies which makes room for various ways of dealing with stereotyping that must not be given attention, this article's position is that this subtle way of presenting certain groups of people creates and drives biases across social, political, financial, economic and other facets of life which negatively impacts and impedes certain cross cultural transactions and interactions and limits the maximization of the full potentials and benefits of national unity. Furthermore, as regards its presence in film, this reflects negatively on the statutory film policy's inability to specifically address the emerging realities countering some of its key objectives.

The issue of provocative stereotyping has also been captured within other spheres. In Olofintuade's, (2017) blog article where the writer treats 10 Nigerian movies showing cultural diversity, one would as well find sub textually hidden undertones of ethnic stereotyping across different movies even as he offered a synopsis on movies. In the synopsis of a movie titled 'The Meeting' captured below, one does not require a careful study of this excerpt to unearth a reinforcement of that Igbo being lovers of money stereotype.

"Set in Abuja, the capital city of Nigeria, The Meeting spotlights Makinde, a Yoruba man, who was sent by his company to secure the signature of a Minister on a contract he had been given. Instead of the one-day trip he had envisaged, Makinde became the 
unwitting hostage of a bribe-taking secretary (who is an Igbo) and the Nigerian patronage system. The movie was produced in 2012 by Mildred Okwo.” (Olofintuade, 2017, Online).

A lot more examples exist in Olofintuade's (2017) blog article and beyond, backing this somewhat bipolar issue. This seemingly subtle negative portrayals in film leaves an impression and plays a rather destabilizing role as regards national unity, a positive image promotion of Nigeria and its various cultures. Again, although the film policy takes a position on encouraging national unity and a positive image promotion of cultures across Nigeria, it does not succinctly offer a position specifically addressing realistic issues such as this; which also goes to buttress the view that the film policy is not advancing with the film industry.

Other issues not addressed by media policies abound in the representation of domestic violence in Nigeria's home video which often takes shape in either verbal abuse, psychological or physical abuse played out on screen. From a certain perspective, the paper backs Oluremi's (2015) position that implied that the inconsequential depiction of acts along the lines of domestic violence in Nigerian films may be a reason for the sustained increase in rate of domestic violence in Nigeria. The true nature of domestic violence in Nigerian films, goes both gender ways i.e. for the male and female according to Utoh-Ezeajugh and Anijah (2017) who analyzed Nigerian film titles and found that domestic violence does not exclusively focus on the domains of and victimization of the female gender as men have been observed to be victims of psychological violence which is often ignited by gender domination desires in a relationship. These and other issues exist within film contents and although their existence and negative influential effect on the film industry, its audience and the nation's image remain consequential, policies have been unable to keep up and address these issues.

\section{Conclusion}

The overarching effect of operating a rather deficient policy in some ways begins to appeal as an exercise in futility as the film industry does not seem to be growing in line with a united and comprehensive policy driven trajectory whose target is that of national development as the core objective of the national media policy. Deductively speaking, it does then appear like the film industry is developing in different directions and heading towards both positive and negative trajectories that may or may not be in line totally with the core principles and ideologies of the nation or its national media policy focused on films.

The current nature of the media policy aimed at administering the film industry requires attention as the industry it was intended for has out paced its dictates, rendering its principles warm and inapplicable to a certain degree. Increasingly, the policies when aligned with the realities of the industry appeal as broad, vague, inapplicable and outdated. In a bid to realign and summon the film industry back on track, the issues highlighted in this article and other observable anomaly, stressed as the film policy's blind spot will require review and guiding policies to direct highlighted issues and more issues either missing in this discuss or likely to emerge after this article.

The position of this article backed by points presented to buttress this perspective remains that the policy is not comprehensive enough to keep up with the industry it is meant to administer. This is because observable realities point to the position that the industry is plagued by issues along the lines of piracy and intellectual property abuses, ethnic division within the movie sector, lack of governmental support as well as a mute position of the film policy on controversial issues in film titles. Due to these observed issues and more, the tendency to realize a multi-faceted bipolar and perceivably wild film industry becomes increasingly possible if the policy and processes of implementation are not revised and updated. The source then being the media policy on film, requires revision to be realigned with the industry's reality, core national ideologies and values as well as fundamental moral and ethical guidelines driving African societies.

\section{Recommendations}

Considering the observation that the media policy is lacking in certain areas and unable to keep up with the pace of the industry, a lot can be done to align the film policies with the developmental strides of the nation. Policy makers, film industry experts as well as specialists in the media and communication discipline may need to study the intricacies, issues observed, emerging issues as well as other complex ramifications of the industry in a bid to understand the trend of things with an aim to draft policies that would totally apply as bespoke policies in line with the realities of the film industry and its goals. Other policies drafted to catalyze monitoring and implementation of principle policies may be required to ensure strategies exist in place to drive and guide implementation.

\section{References}

Adegbembo, A. (2017). Handling Nigeria's Stereotypes. Medium. Available at https://medium.com/@adebayoibidapoadegbembo/handling-nigerias-stereotypes-1c2622643634 (Accessed 14th May 2019)

Adesanya, A. (2005). Nigeria: Rights Acquisitions, Piracy and the Nigerian Film Industry. Available at 
https://allafrica.com/stories/200504260623.html (Accessed 16th May 2019)

Adesokan, A. (2012). Nollywood and the idea of Nigerian cinema. Journal of African Cinemas Vol 4.1. pp. 8198.

Alawode, S. (2013). Ritualism in Nigerian Home Videos. 1st Annual International Interdisciplinary Conference, AIIC 2013, pp. 24-26. Available http://citeseerx.ist.psu.edu/viewdoc/download?doi=10.1.1.1029.9013\&rep=rep1\&type=pdf (Accessed 13th May 2019)

Anyanwu, C. (2015). The prospects and challenges of film publicity in Nigeria. African Journals Online - A Journal of Theatre and Media Studies. Available at https://www.ajol.info/index.php/cajtms/article/view/130395 (Accessed 15th May 2019)

Asemah, E. (2011). Selected Mass Media Theories (First Edition). Jos: Jos University Press.

Baran, J. (2009). Introduction to Mass Communication: Media Literacy and Culture (Fifth Edition). New York: McGraw-Hill Higher Education.

BizzbeeSolutions (2016). Recommendation for Creative Industries in Nigeria. Available at: https://www.bizzbeesolutions.com/wp-content/uploads/2017/04/016-sample-market-research-creativeindustry-Nigeria.pdf (Accessed 12th May 2019)

Buitrago, F., Duque, I. (2013). The Orange Economy: An Infinite Opportunity. Available at: https://publications.iadb.org/bitstream/handle/11319/3659/BID_The_Orange_Economy\%2520Final.pdf (Accessed $1^{\text {st }}$ May 2018)

Chowdhury, M., Landesz, T., Santini, M., Tejada, L. \& Visconti, G. (2008). Nollywood: The Nigerian Film Industry. Harvard Kennedy School. Available at https://www.isc.hbs.edu/resources/courses/moc-course-atharvard/Documents/pdf/student-projects/Nigeria_Film_2008.pdf (Accessed 17th May 2019)

Endong, F. (2019). Pornography and Objectification of Women in Nollywood Films: A Study of Nigerian Actresses' Perception of Acting Sex and Nudity Scenes. Journal of International Women's Studies, 20(2), pp. 58-72. Available at: https://vc.bridgew.edu/jiws/vol20/iss2/5 (Accessed 17th May 2019)

Esiri, J. \& Okunade J. (2014). Nigeria's Communication Policy and News Determination. Journal of Law, Policy and Globalization, Vol.23, pp. 2224-3240 Available at www.iiste.org (Accessed 20 ${ }^{\text {th }}$ May 2019)

Ezegwu, D.; Okechukwu, N.; Etukudo, O. (2016). The Effect of Portrayal of Witchcraft/Voodoo in Nollywood on Nigeria's National Development. Oko Journal of Communication and Information Science (Ojcis). Vol.2 No.1. Available https://www.academia.edu/30968668/THE_EFFECT_OF_PORTRAYAL_OF_WITCHCRAFT_VOODOO IN_NOLLYWOOD_ON_NIGERIAS_NATIONAL_DEVELOPMENT (Accessed 18th May 2019)

Haynes, J. (1995). Nigerian Cinema: Structural Adjustments. Research in African Literatures, 26(3), pp, 97-119. Available at http://www.jstor.org/stable/3820141 (Accessed 12th May 2019)

Ibagere, E. (2015). Globalization and Nollywood: Carving A Niche on The Global Plane. International Journal of African Society, Cultures and Traditions, Vol.2, No.4, pp.1. Available at www.eajournals.org (Accessed $19^{\text {th }}$ May 2019)

Ibbi, A. (2018). Stereotype Representation of Women in Nigerian Films. CINEJ Cinema Journal, 6(2), pp, 49-70. Available at doi:https://doi.org/10.5195/cinej.2017.166 (Accessed 19 ${ }^{\text {th }}$ May 2019)

Idachaba, A. (2018). The Development of Video Film in Nigeria: A Retrospective Account. Research Gate. Available https://www.researchgate.net/publication/323938801_THE_DEVELOPMENT_OF_VIDEO_FILM_IN_NI GERIA_A_RETROSPECTIVE_ACCOUNT (Accessed 19th May 2019)

Kaks, A. (N.D). Objectification and Abjection in Nollywood cinema. Academia. Available at https://www.academia.edu/10144044/Objectification_and_Abjection_in_Nollywood_cinema (Accessed 18th May 2019)

Larkin, B. (2004). Degraded Images, Distorted Sounds: Nigerian Video and the Infrastructure of Piracy, Public Culture Vol 16(2): pp.289-314. (Accessed 23 ${ }^{\text {rd }}$ May 2019)

Lawal-Arowolo, A. (2015). Copyright Exploitation: The 'Nollywood' (Nigeria) Film Market (October 10, 2015). SSRN Elservier. Available at https://ssrn.com/abstract=2694906 or http://dx.doi.org/10.2139/ssrn.2694906 (Accessed 24th May 2019)

LittleJohn, S. \& Foss, K. (2009). Encyclopedia of Communication Theory. London: Sage Publications Inc.

Lobato, R. (2012). Shadow Economies of Cinema: Mapping Informal Film Distribution. London: Palgrave Macmillan

Maton, Y. (2018). The Nigerian Entertainment Industry (Nollywood) Culture and Society. Sociology and Anthropology, 6(8), pp. 657-664. Available at http:/www.hrpub.org DOI: 10.13189/sa.2018.060804 (Accessed 23 $3^{\text {rd }}$ May 2019)

McCain, C. (2013). Nollywood and Its Others: Questioning English Language Hegemony in Nollywood Studies. The Global South, 7.1, pp. 30-54. Available at www.academia.edu (Accessed 21 ${ }^{\text {st }}$ May 2019) 
McQuail, D. (2005). McQuail's Mass Communication Theory (Fifth Edition). London: Sage Publishers.

Michael, E. \& Kayode, O. (2014) Nigeria's Communication Policy and News Determination. Journal of Law, Policy and Globalization Vol. 23 (2014) Retrieved from www.iiste.org ISSN 2224-3240 (Paper) ISSN 22243259 (Online)

Miller, J. (2012). Global Nollywood: The Nigerian Movie Industry and Alternative Global Networks in Production and Distribution. Global Media and Communication. 8(2), pp. 117-133. Available at DOI: $10.1177 / 1742766512444340$ (Accessed 23 $3^{\text {rd }}$ May 2019)

Nigeria Community Radio Coalition (2012). Mass Communication Policy. Available at http://nigeriacommunityradio.org/mascompolicy pg5.php (Accessed 20th My 2019)

Nwafor, N. (2013). Woman as Object of Male Gaze in Some Works of Nigerian Artists. Journal of African Studies. Vol. 2. Available at https://www.Ajol.Info/Index.Php/Mjas/Article/Viewfile/117889/107531 (Accessed 21st May 2019)

Obafemi, O. (2015). Culture Industry and the Economy. Available at https://www.dailytrust.com.ng/news/reflections/culture-industry-and-the- economy/106420.html (Accessed 5th July 2018)

Ochuwa, A. (2017). The Wedding Party- May Experience Huge Loss to Piracy. Concise News Global. Available at https://www.concisenews.global/2017/03/08/wedding-party-lose-n100m-piracy/ (Accessed $18^{\text {th }}$ May 2019)

Offiah, C. (2017). Globalization and the culture/creative industries: An assessment of Nigeria's Position in the Global Space. IOSR Journal of Humanities and Social Science (IOSR-JHSS) Volume 22, Issue 1, pp. 11-23. Available at www.iosrjournals.org (Accessed 19 ${ }^{\text {th }}$ May 2019)

Okiche, W. (2017). How the Wedding Party Became the Biggest Critical and Commercial Nollywood Success Story. Available at https://ynaija.com/wedding-party-became-biggest-critical-commercial-nollywoodsuccess-story/ (Accessed 23 $3^{\text {rd }}$ May 2019)

OkikiApp (2015). Problems faced in the Nollywood Industry. Available at www.okikiapp.com/problems-facedin-the-Nollywood-Industry/ (Accessed 20 $0^{\text {th }}$ May 2019)

Olofintuade, A. (2017). 10 Films That Show Diversity in Nigeria. Culture Trip. Available at https://theculturetrip.com/africa/nigeria/articles/10-films-that-show-diversity-in-nigeria/ (Accessed $19^{\text {th }}$ May 2019)

Oluremi, F. (2015). Domestic Violence Against Women in Nigeria. European Journal of Psychological Research Vol. 2 No. 1, p. 24 Available at https://www.idpublications.org/wp-content/uploads/2014/12/DOMESTICVIOLENCE-AGAINST-WOMEN-IN-NIGERIA.pdf (Accessed 15th May 2019)

Olushola, A. (2016). Portrayal of African Women in Nollywood Films over a Five-Year Period: A Content Analysis of Traits Applying the Stereotype Content Model. Electronic Theses and Dissertations. Paper 3166. Available at https://dc.etsu.edu/etd/3166 (Accessed 20th May 2019)

Onuzulike, U. (2008). Nollywood: The Birth of Nollywood: The Nigerian Movie Industry. Black Camera. Vol. 22, $\quad$ pp. 25-26. Available at https://www.researchgate.net/publication/279533513_Nollywood_The_Birth_of_Nollywood_The_Nigerian Movie_Industry (Accessed 20th May 2019)

Onyenankeya, K., Onyenankeya, O. \& Osunkunle, O. (2019). Sexism and Gender Profiling: Two Decades of Stereotypical Portrayal of Women in Nollywood Films. Journal of International Women's Studies, 20(2), 7390. Available at https://vc.bridgew.edu/jiws/vol20/iss2/6 (Accessed 23rd May 2019)

Opubor, A., Akingbulu, A. \& Ojebode, A. (2010). Broadcast Media Policy In Nigeria. African Communication Research, Vol 3, No. 1 pp. 61-84.

Oyekanmi, O. (2017). Role of Government intervention in the Nigerian movie industry. MA Thesis - Pan-Atlantic University. Available at www.academia.edu (Accessed 12 $2^{\text {th }}$ May 2019)

Schnell, B. (2017). Stop Comparing Nollywood to Hollywood: Reorienting Western Understanding of Nigerian Cinema. Medium. Available at https://medium.com/@bschnell/stop-comparing-nollywood-to-hollywoodreorienting-western-understanding-of-nigerian-cinema-b5cf3152d294 (Accessed 23rd May 2019)

Shaka, F. and Uchendu, O. (2012) Gender Representation in Nollywood Video Film Culture. The Crab: Journal of Theatre and Media Arts. Number 7, pp. 1-30. Available at http://crab.uniport.edu.ng/images/crabjournal_download/Gender\%20Representation\%20in\%20Nollywood $\% 20$ Video\%20Film\%20Culture ShakaUchendu.pdf (Accessed $12^{\text {th }}$ May 2019)

Tade, O. (2016). The piracy threat facing the Nollywood film industry. Newsweek. Available at https://www.newsweek.com/who-and-how-pirates-threatening-nollywood-film-industry-449994 (Accessed 12th May 2019)

Tijani, M. (2018). IMF: Nollywood is Nigeria's second biggest employer. The Cable. Available at https://www.thecable.ng/imf-nollywood-nigerias-second-biggest-employer (Accessed 20th, June 2018)

UNCTAD (2008). Creative Economy Report 2008 - The Challenge of Assessing the Creative Economy: towards informed Policymaking. Available at: http://www.unctad.org (Accessed 13th May 2019) 
Utoh-Ezeajugh, T. \&Anijah, E. (2017). Gender Domination and Domestic Violence in Nigerian Video Films. $A$ Paradigmatic Appraisal UJAH. Volume 18, No. 3. Available at http://dx.doi./org/10.4314/ujah.v18i3.1 (Accessed $13^{\text {th }}$ May 2019)

Uwom, O. \& Alao, D. (2013). Analysis of Media Policies in Nigeria And Ghana. Arabian Journal of Business and Management Review (OMAN Chapter) Vol. 2, No.8.

Van Cuilenburg, J. and McQuail, D. (2003). Media Policy Paradigm Shifts Towards a New Communications Policy Paradigm. European Journal of Communication. Vol 1, pp. 181-207

Ver, W. (2012). Hollywood Dress Habits and its effect on University Students. A paper presentation at the Nollywood, Women and Cultural Identity International Conference held at Benue State University Markurdi - Nigeria $8^{\text {th }}-11^{\text {th }}$ May, 2012.

Vourlias, C. (2017). Meet Africa's Oprah: Nigerian Media Mogul Mo Abudu. Variety, 04 Mar. 2016. Available at https://variety.com/2016/tv/global/nigerian-media-mogul-mo-abudu-1201721173/ (Accessed 12 ${ }^{\text {th }}$ May 2019)

Yaroson, E. \& Asemah, E. (2008). Theories and Models of Mass Communication. Jos: Great Future Press. 